\section{EDUCATION}

Research, Innovation and Solutions on-line ${ }^{\circ}$
Electronic Journal of Research

in Educational Psychology

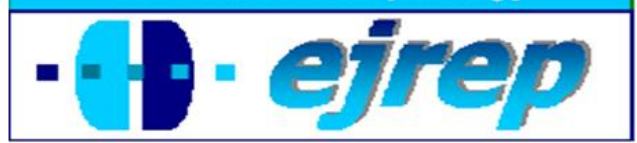

\title{
Pre-Service Teacher Knowledge of Behavior Function: Implications within the Classroom
}

Rachel Youngblom \& Kevin Filter

Psychology Department, Minnesota State University, Mankato

United States of America

Correspondence: Rachel Youngblom. 904 Lakeview Road. Lake Crystal, MN 56055, USA.

E-mail: rachel.youngblom@mnsu.edu

(C) Education \& Psychology I+D+i and Editorial EOS (Spain) 


\begin{abstract}
Introduction. Many teachers lack the skills to effectively deal with behavioral issues when they arise and may not be familiar with behavioral techniques to utilize with students who have behavioral disabilities. The aim of the present study is to understand the extent to which pre-service teachers adequately understand functions of behavior and behavioral principles related to classroom behavior management.
\end{abstract}

Method. Participants included pre-service students who were currently enrolled in an undergraduate university-based educational licensure program. The researcher videotaped three short 4-minute vignettes that displayed adult actors portraying a variety of behaviors.A questionnaire was formulated and given to the participants of the research study that asked them to determine the type of reinforcement being displayed in the vignette as well as to determine the specific function of the behavior in a multiple choice format. Additional background information was gathered from each participant.

Results. Results indicate that pre-service teachers vary in their ability to correctly identify behavior function after viewing video demonstrations of behaviors and that they were even less successful in correctly labeling behavior scenarios as being demonstrations of positive reinforcement, negative reinforcement, or punishment. No variables were identified that predicted participants' accuracy in determining behavior function.

Discussion and Conclusion: These findings support the notion that many pre-service teachers lack a sufficient level of knowledge of behavior function in order to accurately identify the nature of the problem and provide differentiated behavior supports.

Keywords: function, behavior, classroom management, functional behavioral assessment 


\title{
Conocimiento de los futuros docentes sobre la función del comportamiento: implicaciones dentro del aula
}

\begin{abstract}
Resumen
Introducción. Muchos de los maestros sin licenciatura carecen de las habilidades para lidiar efectivamente con los problemas de comportamiento cuando se presentan y es posible que no estén familiarizados con las técnicas actuales para utilizar con los estudiantes que tienen discapacidades de comportamiento. El objetivo del presente estudio es entender el nivel en el cual los maestros, sin licenciatura, actualmente, pueden comprender adecuadamente las funciones de comportamiento y principios conductuales relacionados con la conducta en la aula.

Método. Los participantes que fueron incluidos son estudiantes que actualmente estan matriculados en una universidad con una programa de licenciatura educativa. El investigador grabó tres viñetas de 4 minutos las cual contienen actores actuando algunos comportamientos. Se formuló un cuestionario, el cual se dio a los participantes del estudio de investigación en el que se les pidió que ellos determinaran el tipo de refuerzo mostrado en la viñeta y que determinaran la función específica del comportamiento en formato selecto múltiple. Información adicional fue colectada de cada participante.
\end{abstract}

Resultados. Los resultados indican que los participantes que estan estudiando para ser maestros varían en su capacidad para identificar correctamente la función de comportamiento, después de haber visto las demostraciones de video de varios comportamientos y que tuvieron menos éxito en identificar correctamente los escenarios que demostraban comportamientos de refuerzo positivo, refuerzo negativo, o castigo. No se identificaron variables que predijeran con exactitud si los participantes podian determinar la función de comportamiento.

Discusión y conclusión: Estas conclusiones apoyan la noción de que muchos maestros sin licenciatura carecen un nivel de conocimiento suficiente sobre la función de comportamiento, con el fin de identificar exactamente la naturaleza del problema y proporcionar diferentes apoyos para ayudar con el comportamiento.

Palabras clave: función, comportamiento, gestión del aula, evaluación del comportamiento funcional. 


\section{Introduction}

Complex behaviors unravel within the classroom environment of our schools every day and teachers are often the foremost individuals that are able to give a first-hand account of student academic and aversive behavior. Prior to Public Law 94-142 (Education for All Handicapped Children Act, 1975) students with disabilities were predominately instructed outside of the general education classroom and the general education teachers had little need to possess knowledge of academic or behavioral disabilities. For over the past three decades students with disabilities have been placed in the general education classroom and we find that educators have not become prepared to deal with these changes (Kaf, Zabel, \& Milham, 2007). More specifically, many teachers lack the ability to effectively deal with behavioral issues when they arise (Sugai, Horner, 2002) and are unaware of behavioral techniques to utilize with students who have behavioral disabilities (Kaf, Zabel, \& Milham; Westling, 2010). With greater comprehension of behavioral concepts and knowledge of behavior function, teachers will be more readily prepared to accurately formulate their own hypothesis as to why a target behavior is occurring and will further possess the skill set to make adjustments in the classroom environment accordingly. The purpose of this study was to investigate the extent to which pre-service teachers understand behavioral concepts within the classroom environment. It is hypothesized that pre-service teachers who have been exposed to an adequate amount of behavioral instruction understand behavior function better than those of their peers. Knowledge of behavior function acquired through their preparation program would equip teachers with the necessary tools to effectively manage disruptive classroom behavior.

The reauthorization of IDEA in 1997 (P.L. 105-17) introduced the term positive behavior supports (PBS) that encompasses the principles of behaviorism, the concept of applied behavior analysis, and the process of conducting functional behavioral assessments to guide positive interventions within schools (Sugai, Horner, Dunlap, Heineman, Lewis, Nelson, Scott, \& Liaupsin, 2000). A functional behavior assessment (FBA) can be defined as a systematic process of gathering information to identify problem behaviors that predicts the behavior's occurrence and nonoccurrence and what will maintain the specific behavior (Simonsen \& Sugai, 2009). Although FBAs are often used to fuel the rationale behind individual behavior support plans within the walls of special education, a general education teacher may also use an FBA within the classroom setting as (a) a process to find out triggering antecedents and maintaining reinforcing stimuli for aversive behaviors and (b) restructure the envi- 
ronment to present antecedent stimuli and reinforcing stimuli for desirable behaviors (Simonsen \& Sugai; Sugai et al., 2000). In order to determine function of behavior, teachers must be adequately prepared with knowledge of behavioral principles. Through the entire FBA process, the teacher is collecting valuable data that may be used within a continuum of supports for an individual student.

FBA is a process that can occur at all three levels of prevention: (a) primary, (b) secondary, and (c) tertiary (Filter \& Alvarez, 2012; Filter, Alvarez, \& Zammit, 2012). At the primary level of a functional prevention model, teachers are trying to understand the behavior of the individual students in their regular classroom in order to intervene properly with those behaviors before they become a significant problem. At this level teachers can also document the major problem behaviors of all students on office discipline referral (ODR) forms such that the data can be used within a functional model of decision-making for all students (Clonan, McDougal, Clark, \& Davison, 2007; Flannery, Fenning, McGrath Kato, \& Bohanon, 2011). This requires that ODRs contain information related to antecedents (e.g., location, time of day), behavior (e.g., tardy, defiance), and perceived function (e.g., escape a task, obtain peer attention). Many schools that are implementing positive behavior interventions and supports (PBIS) currently do this (May et al., 2003; Filter \& Alvarez). Schools then use this primary prevention data to develop school-wide interventions to improve behavior. In order for schools to collect accurate and functional ODR data for problem solving, teachers need to have a sufficient understanding of behavior function (Morrison \& Skiba, 2001; Nelson, Benner, Reid, Epstein, \& Currin, 2002; Wright \& Dusek, 1998). At the secondary level of a functional model of prevention, schools provide targeted supports for at-risk students (i.e., those with two to five ODRs) that match the function of their behavior as determined by the collection of simple FBA data (e.g., interviews). The tertiary level of prevention is reserved for students with the most severe and persistent problem behavior (generally with six or more ODRs) and involves intensive FBA procedures and related behavior intervention plans (BIPs). As students move up the levels of prevention the associated supports become more resource-intensive. It is therefore of the most benefit to students and the schools for teachers to take a functional approach to dealing with problem behavior early on in the classroom (McIntosh, Brown, \& Borgmeier, 2008).

Classroom management is a component of any pre-service training for teachers and an imperative behavior of successful teachers. One component of classroom management is the 
ability to control behavior proactively (Sugai \& Horner, 2002). This points to notion that teachers must have a firm grasp on behavioral concepts in order to manipulate setting events and consequences to maximize positive behavior. However, previous research supports the reality that general education teachers often feel ill-prepared to deal with difficult behaviors within the classroom and do not receive the support that they need to effectively improve challenging behavior (Kaf, Zabel, \& Milham, 2007; Westling, 2010). Furthermore, teachers are often unaware of models of support such as response to intervention and positive behavior supports and are not using strategies that are effective when trying to resolve problematic behaviors (Westling; Tillery, Varhas, Meyers \& Collins, 2010).

Although pre-service teachers are generally taught simple concepts of positive and negative reinforcement throughout their course of study (Tillery, Varhas, Meyers \& Collins, 2010), some teacher preparation programs fall short when providing students with classroom management techniques and when teaching extensive skill sets to be able to solve behavioral problems (Meister \& Melnick, 2003). This often remains a persistent area of concern for preservice teachers once they enter the teaching field (Garrahy, Cothran, \& Kulinna, 2005). Beginning teachers have also cited that management of student behavior is also the most difficult concept for them to master (Corbell, Booth, \& Reiman, 2010). Teacher preparation programs often take behavioral management lightly and often assume that students will receive further training in this area once they reach their first teaching experience (Sugai, Horner, \& McIntosh, 2008). These teachers then often gain obscure knowledge and experience by talking with other teachers and through observations, and ultimately rely on inadequate classroom management procedures (Kaf, Zabel, \& Milham, 2007). Therefore, in contrast, when preservice teachers are equipped with adequate training in behavioral principles and classroom management techniques, they are armed with proper tools to be able to solve a plethora of behavioral problems within the classroom before requiring the assistance of a school-based team.

Previous research has examined the utility of technology in order to prepare teachers for real-life classroom situations. Simulating specific functions of behavior demonstrated by students in a classroom via video and CD-ROM have shown to benefit pre-service teachers. Research by Anderson and Lignugaris-Kraft (2006) explored the effects of video-presentation and behavior analytic skills of pre-service elementary teachers. Video clips of scripted scenes were shown to an experimental and control groups and results showed that over time through 
the use of video-based instruction analytical skills of the teachers improved. Additional research by Schweder and colleagues (2008) elaborate on specific advantages that video-based vignettes have when used within the university classroom. Allowing pre-service teachers to view, become aware of functions of behavior and giving them the opportunity to respond before placing them in an actual classroom may prepare them for challenging situations. When pre-service teachers are able to view a behavior and systematically define the function in terms of antecedents and consequences they are able to develop intervention plans to remediate the problematic behavior.

\section{Objective}

The aim of the present study is to understand the extent to which pre-service teachers adequately understand functions of behavior. It is hypothesized that teachers will not be able to determine the function of a student's behavior at a high rate of accuracy. Further, we hypothesize that the amount of exposure to behavioral theory and concepts that the pre-service teachers have, along with their years of professional work with children, will impact how well teachers will be able to accurately detect functions of behavior. Demographics such as participant gender will not predict the accuracy of the function chosen. The skill of accurately detecting function of behavior will be important for classroom management and effective teaching strategies when teachers are presented with challenging behaviors throughout their profession as an educator.

When given an example of a specific behavior, along with identifying the function of the behavior, the participants in the present study were also asked to rate their confidence in the accuracy of their choice of function. Due to our initial hypothesis that pre-service teachers will have a low rate of accuracy when determining function, it is further hypothesized that the participant confidence with not predict the accuracy of the function chosen. The participants were also asked the likelihood of them referring that particular student engaging in the behavior for special education services. One of the hypotheses was that the more knowledge of behavior function the teacher has, the more prepared a teacher would be to handle the problem behavior in the classroom and it is less likely they would refer a student for special education services. 


\section{Method}

\section{Participants}

Participants included pre-service students $(N=37)$ who were currently enrolled in an undergraduate university-based educational licensure program. All student participants were either in their junior or senior year of completing their program and were planning on receiving at least one licensure in a variety of areas of teaching, including special education and non-special education, spanning anywhere from pre-kindergarten to 12th grade. Seventeen students indicated that they were actively pursuing a special education degree and 20 were not. Participants ranged in age from 19 to 39 years old (Males $=12$, Females $=25$ ) and also had various professional backgrounds and experiences. Two professors through the education department from the university campus were contacted and allowed the researcher into their classrooms to conduct the study. The students then volunteered their time to complete the study and consent forms were obtained.

\section{Setting}

All data were collected in a university classroom in a group setting at two different times, approximately 3 weeks apart. In the first session, 21 students participated and 16 students participated in the second session. All students were arranged in rows so that none of the students could converse with one another about the study. The researcher was located at the front of the room during the time the study was conducted and asked the students to refrain from conversing as well. There were no other individuals in the room besides the participants and the researcher.

\section{Instrument}

The researcher videotaped three short 4-minute vignettes that displayed adult actors portraying a variety of behaviors. All actors were filmed in a university classroom to maintain the effect of children sitting in a school classroom. Some of the actors portrayed "children" while one actor portrayed a "teacher" in a classroom. For example, one video vignette showed a "student" actor displaying work avoidance (i.e. head down on desk, crumpling up paper) when the "teacher" actor handed them "homework" sheets to complete which was maintained through negative reinforcement ("teacher" took away homework and sent student out of the room). Another vignette showed a "student" actor displaying adult attention-seeking behaviors (i.e. blurting out answers before called on, following teacher around the room) while con- 
tinuously being positively reinforced by the "teacher" actor (redirection to raise their hand first or to go sit down in their seat). The third vignette showed a "student" actor displaying adult attention-avoidance behaviors (i.e. moving away from teacher, refusing to do work when teacher tries to help) by being negatively reinforced by the "teacher" actor (teacher withdrawing help from student). All vignettes were then shown to three experts in schoolbased behavior supports. Experts were faculty at other universities that had published at least three school-based behavior support studies in peer-reviewed journals. Experts reported the function they perceived for the problem behavior in each vignette. There was $100 \%$ agreement from all experts across all three vignettes regarding the function of the problem behavior.

A questionnaire was formulated and given to the participants of the research study that asked them to determine the type of reinforcement being displayed in the vignette. They were given the options of positive reinforcement, negative reinforcement, or punishment. The participants were also asked the specific function of the behavior in the following multiple choice format: (a) obtain adult attention, (b) obtain peer attention, (c) obtain a task, (d) escape adult attention, (e) escape peer attention, (f) escape a task, or (g) sensory stimulation (these were the same multiple choice options given to the expert raters). Background information was gathered from each participant including the participant's age, gender, education license they were pursuing, how many lifetime professional hours they had accumulated working with children, how many university-supervised hours they had completed working with children, and how many classes they had taken that focused on behavior and behavior theory.

\section{Procedure}

The participants were greeted by the researcher during a regular scheduled class session. The professors had been instructed not to tell the students about the research project, but simply that someone would be asking for their assistance with a project. The researcher distributed the questionnaire complete with the consent form. All participants were asked to read and complete the consent form. Once consent forms had been completed, the researcher asked the participants to complete their background information. When they had finished, they were to turn their attention to the video screen in the front of the room where the researcher played the first vignette video clip streamed from a laptop. When the vignette had finished, the participants were asked to record their answers on their questionnaire. This process was repeated for each vignette until all three had been displayed. When the study was complete, the partici- 
pants were asked to place their questionnaires in a manila envelope at the front of the classroom. Each session lasted approximately 25 minutes.

\section{Statistical Analysis}

Data was assessed through the use of descriptive statistics and frequency counts to gather a majority of the information such as accuracy of correct function chosen. Further, use of correlation statistics was computed with the Statistical Package for Social Sciences (SPSS). The correct function of behavior that the participant chose remained the dependent variable. Independent variables chosen to assess relationship were as follows: years of professional experience, and university-supervised hours working with children, hours of coursework taken that focused on behavioral principles, and participants' confidence in choice of function. A multiple regression was calculated to assess the independent variables of number of university-supervised hours with school-aged students, number of years of professional work with school aged students, and hours of coursework taken that focused on behavioral principles. The number of correctly chosen functions was chosen as the dependent variable. A $t$-test also was used to assess the participant's likelihood of referring the student in the vignette for special education services wherein the likelihood of referral as the dependent variable and gender of the participant was the independent variable.

\section{Results}

Twenty-one out of the 37 pre-service teachers $(56.8 \%)$ chose the correct function for all vignettes. When assessing each vignette individually, 26 out of the 37 (70.3\%) participants correctly chose the function "escape teacher attention"; 31 out of the 37 (83.3\%) participants correctly chose "escape a task"; and 36 out of the 37 (97.3\%) participants correctly chose "obtain teacher attention". Pre-service teachers were also asked to record the correct label for the reinforcement given (i.e. positive reinforcement, negative reinforcement or punishment) for each vignette. When the vignette displaying the student "escaping a task" was shown, 15 out of the $37(40.5 \%)$ of the participants chose the correct label of receiving negative reinforcement. Twenty-two out of the thirty-seven (59.5\%) participants chose the correct label of negative reinforcement when "escaping teacher attention" was displayed. Positive reinforcement was correctly chosen by 34 out of 37 participants (91.9\%) when the vignette displayed a student obtaining teacher attention. Frequency results are summarized in Table 1. 
Table 1. Frequency of participant responses to video vignettes of various behavior functions.

\begin{tabular}{|c|c|c|c|}
\hline Participant Responses & $\begin{array}{c}\text { Vignette } 1 \\
\text { (Escape a Task/Negative } \\
\text { Reinforcement) }\end{array}$ & $\begin{array}{c}\text { Vignette } 2 \\
\text { (Escape Adult Atten- } \\
\text { tion/Negative Reinforce- } \\
\text { ment) }\end{array}$ & $\begin{array}{c}\text { Vignette } 3 \\
\text { (Obtain Adult Atten- } \\
\text { tion/Positive Reinforce- } \\
\text { ment) }\end{array}$ \\
\hline \multicolumn{4}{|l|}{ Function Chosen } \\
\hline Obtain Adult Attention & $5.4 \%$ & $2.7 \%$ & $97.3 \%$ \\
\hline Obtain Peer Attention & $2.4 \%$ & -- & -- \\
\hline Obtain a Task/Activity & -- & $5.4 \%$ & -- \\
\hline Escape Adult Attention & -- & $70.3 \%$ & -- \\
\hline Escape Peer Attention & $2.7 \%$ & -- & -- \\
\hline Escape a Task/Activity & $83.8 \%$ & $21.6 \%$ & -- \\
\hline Sensory Stimulation & $5.4 \%$ & -- & $2.7 \%$ \\
\hline \multicolumn{4}{|l|}{ Descriptor Chosen } \\
\hline Positive Reinforcement & $2.7 \%$ & $35.1 \%$ & $91.9 \%$ \\
\hline $\begin{array}{l}\text { Negative Reinforce- } \\
\text { ment }\end{array}$ & $40.5 \%$ & $59.5 \%$ & $5.4 \%$ \\
\hline Punishment & $56.8 \%$ & $5.4 \%$ & $2.7 \%$ \\
\hline
\end{tabular}

No significance was found when multiple regressions were calculated assessing for relationship of correctly identified function of behavior and number of years of professional experience $(M=2.54, S D=3.88)$ and number of university supervised hours working with children $(M=44.95, S D=31.68)$. Further, no significant relationship was found between hours of coursework taken that focused on behavioral principles $(M=11.95, S D=19.75)$ and correctly identified function of behavior (see Table 2). All correlations between the participants' confidence in their correct choice of function and actual correct function chosen were not significant. 
A $t$-test revealed a significant difference between the likelihood of referring a student for special education services and whether the participant was Male $(M=6.08, S D=1.88)$ or Female $(M=7.64, S D=1.68), t(35)=2.54, p<.05$. Therefore, males were less likely to refer students for special education services than females. However, there was no significance relationship found between the accuracy of identifying the behavior function and the likelihood to refer a student for special education services. Further, there was no significant relationship found between the correct function of behavior chosen and the participant's confidence in their decision.

Table 2. Relationship of Independent Variables to Participants' Number of Correctly Identified Behavior Functions

\begin{tabular}{ccccc}
\hline & B & SE B & $\beta$ & Sig. \\
\hline $\begin{array}{l}\text { Number of years of profes- } \\
\text { sional work with school- } \\
\text { aged students }\end{array}$ & .029 & .027 & .185 & .291 \\
$\begin{array}{c}\text { Number of university- } \\
\text { supervised hours with } \\
\text { school-aged students }\end{array}$ & .003 & .003 & .134 & .451 \\
$\begin{array}{l}\text { Hours of coursework taken } \\
\text { that focused on behav- } \\
\text { ioral principles }\end{array}$ & -.003 & .005 & -.107 & .539 \\
\hline
\end{tabular}

\section{Discussion and Conclusions}

The purpose of this study was to assess pre-service teacher's knowledge of student behavior function and other variables that may impact their knowledge of behavioral principles. The overarching hypothesis stated that teachers do not display a high level of accuracy when assessing the function of a student's behavior. It was also further predicted that the more hours they had completed in previous coursework that centered upon behavioral theories; the more years of professional work experience they had with children; and the more university supervised hours they have fulfilled throughout the coursework of their teacher preparation program would be indicative of their knowledge of the function of behavior. Results indicate that $56 \%$ of teachers were able to correctly identify function of behavior for all three vignettes. In analyzing the patterns of correct and incorrect responses, the escape func- 
tion (negative reinforcement) appeared harder to decipher rather than obtain function (positive reinforcement). From these frequencies we can infer that the function of escape is a more challenging instance of behavior that may be incorrectly identified within a classroom. Teachers often take a characteristic approach to labeling students when dealing with aversive behavior and attribute the behavior to non-function-related variables (i.e., child's personality, need for attention, lack of family stability, parents' level of education, and so on; Bibou-Nakou et al., 1999, 2000; Mavropoulou \& Padeliadu, 2002; Christenson, Ysseldyke, Wang, \& Algozzine, 1983) rather than looking at the behavior in terms of function.

From this study we also find that pre-service teachers are even less skilled at determining the type of reinforcement given to a student that is congruent with the function (positive or negative reinforcement or punishment). This finding is interesting considering previous research that has reported that this is one of the fundamental concept areas of behavioral principles that is being taught in teacher preparation programs (Tillery, Varhas, Meyers \& Collins, 2010). The number of professional years working with children, the number of hours taking classes that included behavioral concepts, and the number of university-supervised hours all did not show any significance in the ability of the participant to accurately determine behavior function. This could be due to the fact that there was not significant variability of these factors between participants and all participants had very little experience within the realm of these specific areas (i.e. few hours of professional experience, very few classes taken, and very little university-supervised hours). However, due to the fact that PBS encompasses several areas, it is argued that individuals need to become familiar with multiple areas of psychology (i.e. ecological, social and community psychology) and education in order to become fully competent in the practice of it (Johnston, Foxx, Jacobson, Green, \& Mulick, 2006). Throughout literature, there is agreement that long-term training and assistance may be needed in order to become proficient in FBA skills (Fox \& Davis, 2005; Scott, Liaupsin, Nelson, \& McIntyre, 2005).

Participant confidence was not found to be an accurate barometer when determining correct function. Even though some participants felt highly confident that their choice of function was correct, this was not always the case; just as lack of confidence in their choice of correct function did not mean that they chose the incorrect function. This did not come as a surprise given the low frequency of correct function of behavior and lack of accuracy when determining the type of reinforcement given to the student in the vignette. Participants who 
had low confidence in their choice of function may have been guessing (either correctly or incorrectly) as to what the function of the behavior was and participants who had high confidence in the choice of function may not fully understand the principles of behavior.

An interesting finding that emerged from this study was the significance of participant gender in the decision to refer a student for special education services in that males were less likely to refer a student than females. This coincides with previous literature that point out the inconsistency of tolerance for behavior across teachers (Morrison \& Skiba, 2001). However, participant gender was not a predictor of accurate detection of behavior function, nor was gender related to confidence in function accuracy. This may indicate that although male teachers are less likely to refer students for special education, it does not mean that problematic behaviors are not occurring within their classrooms and they may still lack the skills to remediate the behaviors effectively.

\section{Limitations}

There are several limitations to this study that should be considered when assessing the results. First and foremost the small sample size of pre-service teachers that volunteered for the study must be addressed. In the future, more participants are required and from multiple teacher preparation programs would be ideal. Volunteers were also included as participants and randomly assigned participants were not available. All students were nested within a classroom together and although attempts were made to dispel any verbal communication, nonverbal communication was not monitored. Also, variability between participants should be extended further to include pre-service teachers with extensive professional experiences and hours of previous coursework encompassing behavioral principles.

Asking pre-service teachers to infer function from a single, brief observation and only three video exemplars may not give the fairest indication of the pre-service teacher's skill in determining behavior function. Therefore, more vignettes may be used in the future. Further limitations that exist may be the "believability" of the actors within the videos and the contrived information that was given to the participants. Although behavior function should not depend on the individual who is expressing the function, the contrived information may be less relevant to the participants. Vignettes used in future research should be as believable as possible. 


\section{Concluding Implications for Future Research}

This study provides a preliminary understanding of pre-service teacher's knowledge of behavior function and the utility of possessing those skills of determining behavior function within a problem solving framework throughout general education classrooms. As our schools continue to move further in the direction of preventative and general education-focused supports, our teachers need to be better prepared with behavioral fundamentals and knowledge of positive interventions. The amount of knowledge and familiarity with the FBA process in order for it to become an efficient practice for an individual, is yet unknown (McIntosh, Brown, \& Borgmeier, 2008). However, previous research indicates that short-term inservices and training in FBAs may not produce function-based support with students (Scott, McIntyre, Liaupsin, Nelson, \& Conroy, 2004; Van Acker, Boreson, \& Gable, 2005). Due to the fact that teachers feel ill-prepared to manage behavior when they graduate from teacher training programs, future research should assess more pre-service teachers' knowledge of behavioral concepts and possible variables that may support teachers in determining accurate function of behavior. Once these variables are explained, they then can be implemented within training programs to support teachers in the general education classroom. This would allow teachers to take a proactive approach to classroom management, hopefully leading to fewer office referrals and less need for intensive supports.

\section{References}

Adelman, H. S., \& Taylor, L. (2003). On sustainability of project innovations as systemic change. Journal of Educational and Psychological Consultation, 14, 1-25.

Anderson, D. H. \& Lignugaris-Kraft, B. (2006). Video-case instruction for teachers of students with problem behaviors in general and special education classrooms. Journal of Special Education Technology, 21(2), 31-46.

Bibou-Nakou, I., Kiosseoglou, G., \& Stogiannidou, A. (2000). Elementary teachers' perceptions regarding school behaviour problems: Implications for school psychological services. Psychology in the Schools, 37, 123-134.

Bibou-Nakou, I., Stogiannidou, A., \& Kiosseoglou, G. (1999). The relation between teacher burnout and teachers' attributions and practices regarding school behaviour problems. School Psychology International, 20, 209-217. 
Christenson, S., Ysseldyke, J.E., Wang, J.J., \& Algozzine, B. (1983). Teachers' attributions for problems that result in referral for psychoeducational evaluation. Journal of Educational Research, 76, 174-180.

Carr E.G, Dunlap G, Horner R.H, Koegel R.L, Turnbull A.P, Sailor W. (2002) Positive behavior support: Evolution of an applied science. Journal of Positive Behavior Interventions, 4, 4-16.

Clonan, S. M., McDougal, J. L., Clark, K., \& Davison, S. (2007). Use of office discipline referrals in school-wide decision making: A practical example. Psychology in the Schools, 44, 19-27.

Corbell, K., Booth, S., \& Reiman, A. (2010). The commitment and retention intentions of traditional and alternative licensed math and science beginning teachers. Journal of Curriculum and Instruction, 4(1), 50-69.

Education for All Handicapped Children Act of 1975, Public L. 94-142; 20 U. S. C. § 1401 et seq.

Elias, M. J., Zins, J. E., Graczyk, P. A., \& Weissburg, R. P. (2003). Implementation, sustainability, and scaling up of social-emotional and academic innovations in public schools. School Psychology Review, 32, 303-319.

Filter, K. J., \& Alvarez, M. (2012). Functional behavioral assessment: A three-tiered prevention model. New York, NY: Oxford University Press.

Filter, K. J., Alvarez, M. E., \& Zammit, K. A. (2012). Functional Behavioral Assessment in a Three-Tiered Prevention Model. In C. Franklin, M. B. Harris, \& P. Allen-Meares (Eds.) The School Services Sourcebook (2 ${ }^{\text {nd }}$ Ed.) (pp.25-36). New York, NY: Oxford University Press.

Flannery, K.B., Fenning, P., McGrath Kato, M., \& Bohanon, H. (2011). A descriptive study of office referrals in high schools. Journal of Emotional and Behavioral Disorders, 112. doi:10.1177/1063426611419512

Fox, J. J., \& Davis, C. (2005). Functional behavior assessment in schools: Current research findings and future directions. Journal of Behavioral Education, 14, 1-4.

Garrahy, D. A., Cothran, D. J., \& Kulinna, P. H. (2005). Voices from the trenches: An exploration of teachers' management knowledge. The Journal of Educational Research, $99(1), 56-62$.

Horner, R. H. (2000). Positive behavior supports. Focus on Autism and Other Developmental Disabilities, 15(2), 97-105. 
Horner, R. H., Dunlap, G., Koegel, R. L., Carr, E. G., Sailor, W., Anderson, J., Albin, R. W., \& O'Neill, R. E. (1990). Toward a technology of "nonaversive" behavioral support. Journal of the Association for Persons with Severe Handicaps, 15, 125-132.

Individuals with Disabilities Education Act of 1997, Pub. L. No. 105-17; 20 U.S.C $\S 1401$ et seq.

Johnston, J. M., Foxx, R. M., Jacobson, J. W., Green, G., \& Mulick, A. (2006). Positive behavior support and applied behavior analysis. The Behavior Analyst, 29(1), 51-74.

Knoster, T., Anderson, J., Carr, E. G., Dunlap, G., \& Horner, R. H. (2003). Emerging challenges and opportunities: Introducing the association for positive behavior support. Journal of Positive Behavior Interventions, 5(3), 183-186. doi: $10.1177 / 10983007030050030801$

Kaff, M. S., Zabel, R. H., \& Milham, M. (2007).Revisiting cost-benefit relationships of behavior management strategies: What special educators say about usefulness, intensity, and effectiveness. Preventing School Failure, 51(2), 35-45.

Mavropoulou, S., \& Padeliadu, S. (2002). Teachers' causal attributions for behaviour problems in relation to perceptions of control. Educational Psychology, 22(2), 191-202.

May, S., Ard, W., III., Todd, A. W., Horner, R. H., Sugai, G., Glasgow, A., \& Sprague, J. R. (2010). School-wide information system. Retrieved from http://www.swis.org

McIntosh, K., Brown, J.A., \& Borgmeier, C. J. (2008) Validity of functional behavior assessment within a response to intervention framework: Evidence, recommended practice, and future directions. Assessment for Effective Intervention, 34(1), 1-16. $10.1177 / 1534508408314096$

Meister, D. G. \& Melnick, S. A. (2003) National new teacher study: Beginning teachers' concerns. Action in Teacher Education, 24(4), 87-94. doi:10.1080/01626620.2003.10463283

Morrison G. M., Skiba R. J. (2001). Predicting violence from school misbehavior: Promises and perils. Psychology in the Schools, 38, 173-184.

Nelson, J.R., Benner, G.J., Reid, R.C., Epstein, M.H., \& Currin, D. (2002). The convergent validity of office discipline referrals with the CBCL-TRF. Journal of Emotional and Behavioral Disorders, 10, 181-188. doi: 10.1177/10634266020100030601

Scott, T. M., Liaupsin, C., Nelson, C. M., \& McIntyre, J. (2005). Team-based functional behavior assessment as a proactive public school process: A descriptive analysis of current barriers. Journal of Behavioral Education, 14, 57-71. 
Scott, T. M., McIntyre, J., Liaupsin, C., Nelson, C. M., \& Conroy, M. (2004). An examination of functional behavioral assessment in public school settings: Collaborative teams, experts, and methodology. Behavioral Disorders, 29, 384-395.

Simonsen, B. \& Sugai, G. (2009). School-wide positive behavior support: A systems-level application of behavioral principles. In, A. Akin-Little, S. G. Little, M. Bray, \& T. J. Kehle (Eds.), Behavioral Interventions in Schools: Evidence-based Positive Strategies, (pp. 125-140). Washington D.C.: American Psychological Association.

Sugai, G., \& Horner, R. H. (2002). The evolution of discipline practices: School-wide positive behavior supports. Child \& Family Behavior Therapy, 24, 23-50.

Sugai, G., Horner, R. H., Dunlap, G., Hieneman, M., Lewis, T. J., Nelson, C. M., Scott, T., Liaupsin, C., Sailor, W., Turnbull, A. P., Turnbull, H. R., III., Wickham, D., Ruef, M., \& Wilcox, B. (2000). Applying positive behavior support and functional behavioral assessment in schools. Journal of Positive Behavior Interventions, 2, 131-143.

Sugai, G., Horner, R. H., \& McIntosh, K. (2008). Best practices in developing a broad scale system of support for school-wide positive behavior support. In A. Thomas \& J. P. Grimes (Eds.), Best practices in school psychology V (pp. 765-780). Bethesda, MD: National Association of School Psychologists.

Schweder, W., Wissick, C. A., \& Ayres, K. (2008). Using Video-based Anchored Instructioto Teach Functional Behavior Analysis. Journal of Special Education Technology, 23(2), $50-55$.

Tillery, A. D., Varjas, K., Meyers, J., \& Collins, A. S. (2010). General education teachers' perceptions of behavior management and intervention strategies. Journal of Positive Behavior Interventions, 12(2), 86-102. doi: 10.1177/1098300708330879

Van Acker, R., Boreson, L., \& Gable, R. A. (2005). Are we on the right course? Lessons learned about current FBA/BIP practices in schools. Journal of Behavioral Education, $14,35-56$.

Warren, J., Edmonson, H., Griggs, P., Lassen, S., McCart, A., Turnbull, A., et al. (2003). Urban applications of school-wide positive behavior support. Critical issues and lessons learned. Journal of Positive Behavior Interventions, 5, 80-92.

Westling, D. L. (2010). Teachers and challenging behavior: Knowledge, views, and practices. Remedial and Special Education, 31(1), 48-63. doi:10.1177/0741932508327466

Wright, J. A. \& Dusek, J. B. (1998). Compiling school base rates for disruptive behaviors from student disciplinary referral data. School Psychology Review, 27(1), 138-147. 